\title{
Hermetyczna wizja zbawienia. Lodovico Lazzarelli (1447-1500) na tle kultury włoskiego odrodzenia
}

Tego bowiem roku, od wcielenia Syna Bożego, 1484, w 11 dzień kwietnia, święto Niedzieli Palmowej, w które cały ortodoksyjny i katolicki Kościół chrześcijański rozpamiętuje ów najwyższy znak czci, zesłany na Chrystusa Jezusa, gdy hebrajskie dzieci wzięły gałązki oliwne i wyszły na jego spotkanie; kiedy Sykstus IV był papieżem, a Fryderyk III Cesarzem Rzymskim, pewien człowiek wystąpił wobec papieża, biskupów, mnichów, książąt i wszelkiego ludu w mieście Rzym, na znak, w imię, słowo i ducha powszechnego, i przerażającego sądu [...].

Wyglądał on na około trzydzieści trzy lata, średniego wzrostu, o wdzięcznej i wyprostowanej postawie, bystrej i znakomitej inteligencji, z chudą i czcigodną twarzą, z brodą i gładkim ciałem. Jego oczy były żywe, a kasztanowe włosy opadały pofalowane; nigdy nie uczył się gramatyki czy retoryki, lecz był dobrym i elokwentnym mówcą [...].

Słońce już wzeszło, gdy ten człowiek, o którym mówimy, ubrany w srebrny, jedwabny płaszcz i czarną togę, obwiązany złotym pasem, obuty w czerwone, ozdobione purpurą buty, wjeżdżał na czarnym, rżącym koniu. [...] Zsiadłszy później z niego, włożył na swe stopy sandały i przyodział się w płócienną, pokrwawioną szatę. Swoje włosy, rozdzielone pośrodku na modłę Nazareńczyka, udekorował zbryzganą krwią koroną cierniową, na której przedzie, u góry znajdował się dysk wykonany ze srebrnej płyty w kształcie półksiężyca, na którym można było odczytać takie mistyczne orędzie Ducha Świętego: „To jest syn mój, Pimander, którego ja wybrałem. Pimander ten jest bowiem moim najwyższym i przybywającym dzieckiem, w którym mam upodobanie, by wy- 
pędzał demony i obwieszczał mój sąd i prawdę u pogan. Nie ukrywajcie go, lecz słuchajcie i bądźcie mu posłuszni z całą bojaźnią i czcią; [tak] mówi Pan Bóg i Ojciec wszelkiego talizmanu całego świata, Jezus z Nazaretu”.

Po czym zawiesił kałamarz na lędźwiach i wziął w rękę pióro o siedmiu węzłach, niczym berło. Na piersiach, na czarnym kwadracie, i na plecach, na niebieskim [kwadracie] oraz na okrągłym złotym dysku, niczym na napierśniku wyrocznym i efodzie Aarona, [...] wyryte było thau: imię i symbol Boga najwyższego. [...]

Następnie, ów boski mąż, uklęknął na trawie [i], kierując swe oczy ku niebu i do Boga, Ojca wszystkiego oraz wznosząc swój umysł, oddał się cichej modlitwie. Gdy skończył, ten, który niewiele wcześniej popędzał ostrogami swego żwawego i bojowego konia, [teraz] upokorzył siebie [...] i dosiadł wolnego, białego i taniego osła. [...]

Po wygłoszeniu kazania wyjął on z sakwy wiele kart papieru, na których wypisane były słowa, jakie wcześniej powiedział, i rozrzucił je wśród ludu, jak gdyby były one latającymi zwojami. Wypisany był na nich następujący tytuł i inskrypcja: „Ja, Giovanni Mercurio z Correggio, anioł mądrości Pimandra, w najwyższej i największej ekstazie ducha Jezusa Chrystusa, we wszystkich tych wodach królestwa, dla niewielu [wybranych] głoszę wielkim głosem ewangelię". 2

1 Jeśli nie zaznaczono inaczej, wszystkie komentarze w cytowanych tekstach i przekładach pochodzą od autora artykułu [D. N.].

2 „Anno hoc enim ab incarnatione filii dei .M.ccc.lxxxV tertio idus aprilis in solemnitate palmarum: in qua omnis catholica orthodoxaque christianorum ecclesia illius maximae venerationis erga christum iesum collatae meminit: quando pueri hebreorum accipientes palmas olivarum illi obviam exierunt: sedente Xysto quarto pontifice maximo: \& imperante romanorum caesare Frederico tertio: Pontifici presulibus sacerdotibus principibus tortique populo homo quidam in signo nomine verbo ac spiritu universi atque tremendi iudicis in urbe roma manifestus apparuit [...]: trigesitum tertium aetatis prae se ferens annum: mediocris gracilis erectaeque staturae agilis \& optima alacritate dispositus: Macilento \& venerabili vultu: barba $\&$ toto corpore glabello: oculis variis crinibus castaneae similibus cultis undantibus $\&$ circumdemissis: numquam grammaticam $\&$ oratoriam edoctus: lingua tamen diserta \& eloquio facundo [...]. Exorto iam sole hic homo de quo loquimur: argentea dypploide serica $\&$ nigra toga vestitus aureo cinctus cingulo caligis coccineis imphulaque tyrio colore fucata ornatus: super nigrum frementemque equum ascendit. Tum [...] de equo descendes pedibus thalaria sumpsit: lineisque sanguine profusis superinduitur \& cingitur: capillosque secundum morem nazareorum discriminans: spinea \& cruentata decoravit corona: Super qua fronti imminens argentea \& corniculata instar lunae lamina connectebatur: in qua hoc spiritus sancti oraculum mysticae exaratum legebatur: Hic est puer meus Pimander quem ego elegi. Pimander enim hic ipse parvulus 
Cytowany tutaj fragment z Epistola Enoch (1490) Lodovica Lazzarelliego jest niewątpliwie najobszerniejszym ze znanych nam źródeł o życiu i naukach tej niezwykle ekscentrycznej i tajemniczej postaci, jaką bez wątpienia był Giovanni Mercurio da Correggio (ok. 1451-po 1503)33. Jednakże, nawet to dzieło nie jest w stanie wyjaśnić nam, w jakich okolicznościach Giovanni zaczął swe nauki głosić i dlaczego zrezygnował z hermetycznego mistycyzmu na rzecz praktycznej alchemii ${ }^{4}$. $Z$ omawianego listu dowiadujemy

meus altissimus $\&$ accrescens in quo $\&$ mihi sic bene complacui eiicere demonia: $\&$ facere iudicium $\&$ veritatem meam in gentibus. Nolite prohibere eum: sed ipsum cum omni metu \& veneratione audite ac observante: dicit dominus deus \& pater omnis thelesmi totius mundi Iesus nazarenus. Deinde attramentarium suspendit in renibus: Septinodiam harundinem pro sceptro in manu accepit: In pectore, super nigro quadro $\&$ in tergo super caelestino in modum rationalis iudicii \& superhumeralis Aaron [...] opere celaturae insculptum thau: nomen ac signum summi dei supposuit: in quo quae sculpta signataque erant [...]. Vir ille divinus [...] positis in gramine genibus sublatis ad caelum oculis ad omnium patrem deum mente elevata tacita deprecatus est oratione: qua perfecta qui paulo ante alacrem armisque accomodum suum equum calcaribus presserat: humiliatus [...] venali alboque asino supersedit. [...] Hic dictis complures papiros in quibus haec quae palam dixerit verba descripta fuerant: e pera accipiens in populum tanquam volantia volumina dispergebat: in quibus hic titulus \& superscriptio legebatur. Ego Ioannes mercurius de corigio sapientiae angelus Pimanderque in summo ac maximo spiritus Iesu christi excessu: hanc aquam regni pro paucis sic super omnes magna voce evangelizo" (L. Lazzarelli, Epistola Enoch 5. 1-6. 4, 7. 1, 8. 3-8. 3. 1, w: Id., The Hermetic Writings and Related Documents, ed. W. J. Hanegraaff, R. M. Bouthoorn, Arizona Center for Medieval and Renaissance Studies, Tempe — Arizona 2005, s. 118-136. Jeśli nie zaznaczono inaczej, wszystkie przekłady tekstów źródłowych lub fragmentów obcojęzycznych z literatury przedmiotu pochodzą od autora artykułu [D. N.]. Por. też: M. J. B. Allen, At Variance: Marsilio Ficino, Platonism and Heresy, w: Platonism at the Origins of Modernity. Studies on Platonism and Early Modern Philosophy, ed. D. Hedley, S. Hutton, Springer, Dordrecht 2008, s. 33; W. Shumaker, The Occult Sciences in the Renaissance. A Study in Intellectual Patterns, University of California Press, Berkeley — Los Angeles — London 1973, s. 234-235; D. P. Walker, Spiritual and Demonic Magic from Ficino to Campanella, The Pennsylvania State UP, Pennsylvania 2000, s. 69-70.

3 Por. T. Churton, The Golden Builders: Alchemists, Rosicrucians, and the First Freemasons, Weisel Books, York Beach 2005, s. 46; W. J. Hanegraaff, Lodovico Lazzarelli and the Hermetic Christ. At the Sources of Renaissance Hermetism, w: L. Lazzarelli, The Hermetic Writings..., s. 22. O pozostałych źródłach por. T. Churton, op. cit., s. 46-47; W. J. Hanegraaff, op. cit., s. 22, 27, 31-41; D. B. Ruderman, Giovanni Mercurio da Correggio's Appearance in Italy as Seen through the Eyes of an Italian Jew, „Renaissance Quarterly” 1975, 28, s. 309-322.

4 Por. W. J. Hanegraaff, op. cit., s. 37-44; D. B. Ruderman, op. cit., s. 309. Do znanych dzieł Giovanniego Mercuriego da Correggio należą: Sonetto (po 1492; sonet ten, mówiący o sferach niebieskich i powrocie człowieka do Boga, komentowany był przez 
się jeszcze, że wizyta Correggia w Rzymie w r. 1484 nie była jego pierwszą misją ewangelizacyjną w tym mieście. Jak wspomina Lazzarelli, Giovanni pojawił się tam już trzy lata wcześniej, głośno obwieszczając sakralne orędzie wypisane na „świętym tomie Biblii, zapięczętowanej mistycznie siedmioma pieczęciami"' . Nie wiadomo, czego dokładnie nauczał, lecz, jeśli wierzyć autorowi Epistola Enoch, już wówczas w jego poglądach dostrzec można było elementy hermetyczne ${ }^{6}$. Właśnie w 1481 r., pod wpływem nauczania Giovanniego da Correggio, opuścił Lazzarelli, jak sam pisze, poetyckie wzgórza Parnasu i podążył za prorokiem na mistyczną Górę Synaj ${ }^{7}$. Lodovico pragnął widzieć w Giovannim swego duchowego mistrza, ojca i nauczyciela ${ }^{8}$. W odzie poprzedzającej tekst Asklepiusza mówi o da Correggio niemalże jak o bogu:

Ojcze Merkuriuszu i — przez pobożność ojcowską — nauczycielu,

Bądź pozdrowiony, który zdajesz mi się istotą boską.

Ty mnie na nowo zrodziteś [swym] eterycznym nasieniem,

I nauczyłeś mnie rodzić się raz jeszcze bez żadnej li szkody.9

Carla Sosennę z Ferrary), Oratio (Rzym 1499; mowa nakłaniająca grzeszników do nawrócenia), Exhortationes (Lyon 1501; dzieło zachęcające wszystkich chrześcijan do krucjaty przeciw Turkom i innym niewiernym). Traktatami, w których wyraźne stają się akcenty alchemiczne, są: Contra Pestem (wyd. po 1501) i De Quercu Iulii Pontificis sive de lapide philosophico (ok. 1503-1513).

5 L. Lazzarelli, Epistola Enoch 12. 1, 12. 2, s. 140, 146. Por. W. J. Hanegraaff, op. cit., s. 23-27.

6 Por. L. Lazarelli, Epistola Enoch 12. 1. 1., s. 142 i komentarz s. 143, przyp. 127 oraz W. J. Hanegraaff, op. cit., s. 25. Nie odpowiedziano jeszcze na pytanie o to, czy rzeczywiście dzięki Mercuriowi Lazzarelli zainteresował się hermetyzmem.

7 „Relictis parnasi / collibus caeterisque omnibus ad monetm syon primus eum sum protinus insequutus" (L. Lazzarelli, Epistola Enoch 13. 1, s. 148). Metafora ta powraca jeszcze w innych utworach Lazzarelliego (por. Id., [przedmowa do Pimandra Ficina], w: Id., The Hermetic Writings..., s. 154; Id., [przedmowa do Diffinitiones Asclepii], w: ibidem, s. 160). Por. też T. Churton, op. cit., s. 45; W. J. Hanegraaff, op. cit., s. 24, 44 i n.

8 Por. „[...] o mi praeceptor, o dulcissime mi pater Ioannes Mercuri. [...] o dux o vitae meae concultissime rector [...]. Ibi multa de Hermete nostro [...] quod patrem tuum avum meum [...]" (L. Lazzarelli, [przedmowa do Pimandra Ficina], s. 152, 154); „[...] o pater o mi benignissime praeceptor Ioannis Mercuri [...]” (L. Lazzarelli, [przedmowa do Diffinitiones Asclepii], s. 162).

9 „Mercuri pater et patria pietate magister, / O mihi divini numinis instar ave./ Aethereo tu me genuisti semine rursus / Atque iterum nasci me sine fraude doces" (L. Lazzarelli, Carmen, w: Id., The Hermetic Writings..., s. 158). 
Nie powinno nas dziwić to boskie porównanie, skoro Giovanni, zdaniem Lazzarelliego, wielkością i cudownością swej postaci nie tylko dorównał antycznym mędrcom egipskim, hebrajskim, greckim czy łacińskim, ale nawet dalece ich przewyższył. I, stwierdza dalej Lodovico, nie widziano dotąd bardziej „cudownego sakramentu” nad „owego boskiego, chrześcijańskiego męża”, który pojawił się „w tym naszym najbardziej nieszczęśliwym i ciemnym wieku" ${ }^{10}$. Porównanie z bogami usprawiedliwiało żywione przez Lazzarelliego euhemerystyczne przekonanie, że pogańscy bogowie byli doskonałymi i prawdziwymi ludźmi i mędrcami ${ }^{11}$. Nie jest więc bynajmniej, tak powszechną w humanistycznej retoryce, hiperbola czy też poetycką metaforą fragment ukazujący Giovanniego przewyższającego pradawnego mędrca, Hermesa Trismegistosa:

Ty tylko, przez sekretne jaskinie ojca Hermesa

Wszystkim nieznanymi wszedłeś i powróciłeś drogami.

Czego wcześniej on nauczał ludzi, teraz ty uczyć

Począłeś; owszem, ojcze, ty nawet lepiej nauczasz.

Owo więc święte imię należy się słusznie i tobie. ${ }^{12}$

W studiach nad „boskimi księgami Hermesa”13 kierowała Lazzarellim nie tylko zwykła poznawcza ciekawość, ale i przekonanie, że oto tutaj, na jego oczach, odsłania się odwieczna, Boska tajemnica, a przed pogrążonym w zepsuciu światem pojawia się niepłonna nadzieja wiecznego zbawienia. Hermetyczna pasja Lodovica Lazzarelliego zaowocowała stworzeniem przez niego dzieła o hermetycznej drodze zbawienia - Crater Hermetis. Uznać je też trzeba za najbardziej wyrazisty przykład chrześcijańsko-hermetycznego synkretyzmu, jaki tylko przetrwał do naszych czasów.

10 Por. L. Lazzarelli, Epistola Enoch 3. 1., s. 110.

11 Por. L. Lazzarelli, [przedmowa do Pimandra Ficina], s. 156. Euhemeryzm ten pojawia się już w Argumentum ad Pimandrum Ficina (Marsilii Ficini, Philosophi, Platonici, Medici atque Theologi omnium praestantissimi, Operum, t. 2, ex officina Henricpetrina, Basileae 1576, s. 1836).

12 „Tu patris Hermetis solus secreta per antra / Omnibus ignotas isque redisque vias. [...] / Quae prius ille homines docuit, nunc ipse docere / Incipis, immo pater tu potiora doces. / Illius ergo sacrum merito tibi nomen inhaeret" (L. Lazzarelli, Carmen, s. 158).

13 Por. L. Lazzarelli, [przedmowa do Pimandra Ficina], s. 152. Symbolika dwóch rajskich drzew obecna jest także (poza obszernymi fragmentami Crater Hermetis) na początku Epistola Enoch (I. 1, s. 108). 
Nim jednak przejdziemy do dalszej części wywodu poświęconego Crater Hermetis, należy wyjaśnić, w jaki sposób rozumiemy znaczenie terminu „hermetyzm”. Wielu uczonych rozumie go - sensu lato jako dzieje alchemii czy też dzieje różnych historycznych przejawów myślenia za pomocą analogii, inni zaś wolą postrzegać go — sensu stricto - jako specyficzne wykorzystanie traktatów Corpus Hermeticum we włoskiej renesansowej filozofii ${ }^{14}$. Jakby tego było mało, termin „hermetyczny" występuje również w mowie potocznej, gdzie oznacza wszelkiego rodzaju ezoteryzmy, okultyzmy i magię, włączając w swój obręb wszystkie wymykające się jawnemu dyskursowi dziedziny wiedzy.

Próbą zaradzenia temu terminologicznemu zamieszaniu był postulat, jaki pojawił się w latach sześćdziesiątych ubiegłego wieku, by w literaturze fachowej oddzielać „hermetycyzm” (hermeticism), czyli naukę alchemii, jak również kabałę, teozofię chrześcijańską, okultystyczną filozofię czy magię, od „hermetyzmu” (hermetism), czyli powstałego w starożytności zbioru religijnych pism (Hermetica) i bezpośrednio inspirowanej nimi literatury ${ }^{15}$. Tak też, w wąskim znaczeniu, i my pojmujemy „hermetyzm" jako termin związany z Hermetica właśnie.

Hermetica są pismami, których autorstwo przypisywano w starożytności albo samemu Hermesowi Trismegistosowi, egipskiemu mędrcowi, albo też jednemu z jego uczniów. Zalicza się do nich zbiór siedemnastu krótkich, greckich traktatów określanych mianem Corpus hermeticum, łaciński dialog Asklepiusz, armeńskie Definicje dla Asklepiusza, fragmenty przekazane przez ojców Kościoła (Laktancjusza i Augustyna), wyciągi z florilegium Stobaeusa (zwłaszcza Kore Kosmu) oraz odkrytą niedawno w Nag Hammadi (Codex VI, 6) Rozmowę o ósmej i dziewiątej [sferze] ${ }^{16}$.

14 Por. F. Ebeling, The Secret History of Hermes Trismegistus. Hermeticism from Ancient to Modern Times, transl. D. Lorton, Cornell University Press, Ithaca - London 2005, s. 1.

15 Por. A. Faivre, Renaissance Hermeticism and the Concept of Western Esotericism, w: Gnosis and Hermeticism from Antiquity to Modern Times, ed. by R. van der Broek, W. J. Hanegraaff, State University of New York Press, New York 1998, s. 109-110; B. P. Copenhauer, Natural Magic, Hermeticism and Ocultism in Early Modern Science, w: Reappraissals of the Sciencific Revolution, ed. by D. C. Lindberg, R. S. Westnam, Cambridge UP, New York 1990, s. 289; W. J. Hanegraff, op. cit., s. 2, przyp. 1; W. Shumaker, op. cit., s. 206.

16 Por. R. van den Broek, Gnosticism and Hermetism in Antiquity, w: Gnosis and Hermeticism, op. cit., s. 5; F. Ebeling, op. cit., s. 18-19; T. Zieliński, Hermes Trismegistos. Studjum, Zygmunt Pomarański, Zamość 1921, s. 56. Klemens Aleksandryjski (Stromata VI, 4) podaje, że było 36 ksiąg Hermesa zawierających całą filozofię Egipcjan oraz 6 ksiąg o zagadnieniach 
Jak się obecnie ocenia, Hermetica, przynajmniej w znanym nam kształcie, powstały około II-III w. naszej ery w rejonie Aleksandrii ${ }^{17}$.

Podobnie synkretyczne, wręcz heterogeniczne treściowo, wydają się hermetyczne pisma. Część z nich stanowią traktaty teologiczno-filozoficzne, część - traktaty magiczne, astrologiczne, alchemiczne, a pojawiające się w nich idee są niezwykłą mieszaniną wątków zarówno arystotelesowskich, platońskich, stoickich i pitagorejskich, jak również egipskich, żydowskich czy irańskich ${ }^{18}$. Gdybyśmy więc próbowali rozpatrywać ich zawartość jedynie z perspektywy systemu przekonań, łatwo odnaleźlibyśmy wiele niedomówień, a być może nawet sprzeczności. Jednakże, jak przekonuje Mahé:

[...] hermetyzm nie jest systemem filozoficznym, lecz duchową drogą, naczelnym celem literatury hermetycznej nie jest wyłożenie teoretycznego nauczania, lecz wywołanie duchowego postępu, wzniesienie jednostki z królestwa materialnych ciał [...] aż do najwyższego Boga, który jest Nous i czystym, bezgranicznym oraz niecielesnym światłem. ${ }^{19}$

medycznych. Manetho twierdzi, że ksiąg tych było aż 36 525, a Seleucus —że 20000 (por. F. Ebeling, op. cit., s. 9). Korzystam z następujących wydań i ttumaczeń: Corpus Hermeticum (dalej jako CH) - Corpus Hermeticum, t. I, passim, II, s. 197-256, ed. A. D. Nock, trad. A.-J. Festugiére, Sociéte d'Édition „Les Belles Lettres”, Paris 1960; The Way of Hermes. New Translations of The Corpus Hermeticum and The Definitions of Hermes Trismegistus to Asclepius, transl. C. Salaman, D. van Uyen, W. D. Wharton, J.-P. Mahé, Inner Traditions, Rochester - Vermont 2004, s. 17-92; Asclepius (dalej jako A) - Corpus Hermeticum, op. cit., t. II, s. 257-404; Pseudo-Apulejusz, Asklepiusz, czyli rozmowa z Hermesem Trismegistosem, przet. K. Pawłowski, w: Apulejusz z Madaury, O bogu Sokratesa i inne pisma, PWN, Warszawa 2002, s. 173-219 (dalej jako A); Definicje dla Asklepiusza (dalej jako DA) — The Way of Hermes..., s. 109-122; Rozmowa o ósmej i dziewiatej [sferze] (dalej jako R) — The Discourse on the Eighth and Ninth, transl. J. Brashler, P. A. Dirkse, D. M. Parrott, w: The Nag Hammadi Library. The Definitive Translations of the Gnostic Scriptures complete in one volume, ed. J. M. Robinson, Harper, San Francisco 1990, s. 183-185.

17 Por. F. Ebeling, op. cit., s. 12, 14; G. Quispel, Gnoza, przet. B. Kita, PAX, Warszawa 1988 , s. 85.

18 Por. F. Ebeling, op. cit., s. 9, 31; R. A. Segal, 'Poimandres' as a Myth. Scholarly Theory and Gnostic Meaning, Mounton de Gruyter, Berlin 1986, s. 1. Ta złożoność nauk hermetycznych sprawia, że błędem jest traktowanie każdej idei zawartej w Hermetica jako idei źródłowo hermetycznej, a takie błędy, jak przypomina Brian Vickers (Id., Introduction, w: Occult and Scientific Mentalities in the Renaissance, ed. B. Vickers, Cambridge UP, Cambridge, New York 1984, s. 3), zwłaszcza wśród badaczy renesansu, niejednokrotnie się zdarzają.

19 J.-P. Mahé, Introduction, w: The Way of Hermes..., s. 102. Por. R. van den Broek, op. cit., s. 3-4. 
Na tym wznoszeniu, oznaczającym powrót upadłego człowieka do boskiego źródła, zasadza się hermetyczna nauka o zbawieniu. W tym powrocie do Boga, „drodze nieśmiertelności” (R 185), wyróżnia się cztery etapy (stany): Episteme (przebudzenie), Logos (proces osiągania dojrzałości), Nous (wizja boskiego intelektu) i (osiągana za jej sprawa) Gnôsis ${ }^{20}$. Największy nacisk kładziony jest zawsze na moment objawienia (Nous) — nagrody dla pobożnych dusz (CH I, 22; CH IV, 3). Dzięki otrzymywanej w objawieniu gnozie człowiek dowiaduje się o swym boskim pochodzeniu i w ten sposób powraca do swej pierwotnej siedziby: „Jeśli przeto uświadomisz sobie, że jesteś bytem z życia i światła i że zostałeś z nich utworzony, wrócisz do życia” (CH I, 21). Tak więc, jedyny sposób na zbawienie człowieka wiąże się, według hermetyzmu, z — opisywanym często w mniej lub bardziej metaforycznych kategoriach - narodzeniem na nowo, gnozeologiczną przemianą umysłu (CH XIII, 1-3). Jak czytamy w dziesiątym traktacie Corpus hermeticum: „To jest jedyne zbawienie dla człowieka: gnoza o Bogu” (CH X, 15).

Czy oznacza to zatem, że mamy tu do czynienia z pewną odmianą gnostycyzmu, religią, w której kluczową rolę odgrywa element gnozy? Odpowiedź nie jest wcale tak oczywista, zwłaszcza że doświadczenie gnozy na początku naszej ery wysoko oceniali nie tylko „gnostycy” par excellence, lecz również w ogóle przedstawiciele filozoficznych kręgów cywilizacji aramejskiej i grecko-rzymskiej. Nawet w Ewangelii Jana $(17,3)$ Jezus przy Ostatniej Wieczerzy nie mówi o wierze (pistis), lecz o poznaniu (gnosis) ${ }^{21}$. Nie oznacza to jednak wcale, że Ewangelia Jana jest pismem gnostyckim, podobnie jak i hermetyczne wzmianki o gnozie nie muszą skutkować natychmiastowym uznaniem hermetyzmu za przejaw gnostycyzmu. Kiedy bowiem gnostycyzm uważa, że ludzki umysł (nous) nie jest w stanie w żaden sposób pojąć natury Boga, hermetyzm podobnie jak pewne odmiany chrześcijańskich teologii uznaje, że choć Bóg jest w swej istocie nieznany, to jednak może być przez ludzki umysł — jakkolwiek niedoskonale — pojęty. Ponadto, gnostykom świat jawi się jako zły twór przeciwnego Najwyższemu Bogu demiurga, podczas gdy w hermetyzmie świat - kosmos przemawia wręcz za istnieniem Najwyższego Boga (CH XII, 21) i nazywany jest niekiedy

20 J.-P. Mahé, La Voie d'immortalité à la lumière des "Hermetica” de Nag Hammadi et de decouvertes plus récentes, „Vigiliae Christianae”, 1991, 45, s. 351.

21 Por. G. Quispel, Gnosticism, w: Gnostica, Judaica, Catholica. Collected Essays of Gilles Quispel, ed. by J. van Oort, Brill, Leiden 2008, s. 155. 
wprost Jego obrazem (A XXVI) ${ }^{22}$. Tak więc, nawet wówczas, gdy odnajdujemy w hermetyzmie wyrazy poczucia obcości człowieka w świecie, to jednak zawsze towarzyszy im założenie, że umysł człowieka nie jest bezużytecznym narzędziem i że kosmos jako taki raczej wspiera niż hamuje wysiłki człowieka do osiągnięcia zbawienia ${ }^{23}$.

Jeszcze do niedawna panowało wśród uczonych przekonanie, pochodzące od Festugière'a, o źródłowo greckim charakterze zawartych w Hermetica idei, dla których elementy egipskie stanowią jedynie dekorację. Jednak obecnie coraz więcej badaczy skłania się ku tezie o egipskim pochodzeniu doktryn hermetycznych. Według Strickera, treści wyrażone w Hermetica są egipskie, ale zostały ujęte w pojęciową siatkę zaczerpniętą z greckiej filozofii ${ }^{24}$. Podobnie Garth Fowden w książce Egyptian Hermes (1985) opowiedział się za wpływem egipskim na aleksandryjski hermetyzm, czym restytuował de facto poznawczą wartość uwag zawartych w samym Corpus Hermeticum. W traktacie szesnastym (CH XVI, 1-2) dowiadujemy się bowiem, że egipski, pierwotny język nauk Hermesa Trismegistosa lepiej oddawał ducha słów, i że niejasne już wcześniej nauki zupełnie się zaciemniły po przełożeniu ich na grekę. Szalę przeważyły wreszcie niedawne badania Kingsleya $(1993)^{25}$ nad znaczeniem i pochodzeniem imienia Poimandresa, utożsamianego z Nous bohatera pierwszego i jedenastego traktatu Corpus Hermeticum. Kinglsey, po wnikliwej analizie leksykalnej, odrzuciwszy grecką

22 W obrębie Hermetica istnieją fragmenty bardziej zbliżone do gnostycyzmu. Jednakże, gdy spojrzy się na nie z perspektywy całości, dają się one wpisać w optymistyczną wizję świata. Dla przykładu, jeśli nawet w CH IV, 4 nazywa się świat „sumą zła”, a w CH IX, 4 stwierdza się, że krajem zła jest ziemia, to jednak, dzięki innym fragmentom, które wprowadzają prywatywną ontologię zła, miejsca te zatracają swoje "gnostyckie ostrze”. Problem zła podnoszony jest w: A XVI; CH IV, 8. W CH XIV, 7, stwierdza się jednoznacznie, że Bóg nie jest przyczyną zła, by wreszcie w DA X, 4 wprost określić, że „Zło jest brakiem dobra”.

${ }_{23}$ Por. R. van den Broek, op. cit., s. 6-17; F. Ebeling, op. cit., s. 32; N. GoodrickClarke, The Western Esoteric Traditions. A Historical Introduction, Oxford UP, New York 2008, s. 29.

24 Por. F. Ebeling, op. cit., s. 38.

25 Por. P. Kingsley, The Etymology of the Name of Poimandres and the Origins of the Hermetica, „Journal of the Warburg and Courtauld Institutes”, 1993, 56, s. 1-24. Por. również R. Marcus, The Name Poimandres, „Journal of Near Eastern Studies”, 1949, 8, s. 40-43. 


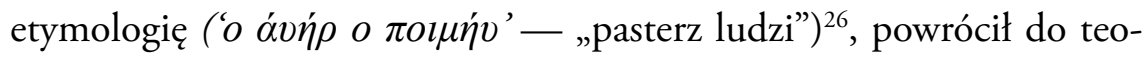
rii Griffitha i Reizensteina z początku XX w., o demotycznych czy też koptyjskich korzeniach tego słowa. „Poimandres” pochodzi zatem od egipskiego słowa $P$-eime n-re znaczącego „Wiedza Re”. Określenie to, zgodnie z egipskimi mitologiami, pozwala na utożsamienie go z Totem.

Tym samym potwierdzenie znajdują poglądy neoplatonika z III w., Jamblicha, który w De mysteriis, zbijając argumenty Porfiriusza z Listu do Anebo, bronił egipskiego pochodzenia Hermetica:

Te dokumenty [...], które krążyły pod imieniem Hermesa, zawierają hermetyczne nauki, nawet jeśli często wykorzystują terminologię filozofów; bowiem zostały one przełożone z egipskiego języka przez ludzi obytych z filozofią. ${ }^{27}$

Słowa te są o tyle ważne, że to Jamblich jako pierwszy zaadaptował myśl hermetyczną do filozofii neoplatońskiej i że to właśnie jego dzieła były pierwszymi wśród tych, jakie w XV w. przełożył na łacinę późniejszy tłumacz Corpus Hermeticum, Marsilio Ficino (1433-1499) ${ }^{28}$.

Przedmiotem zainteresowania stanu badań nad renesansową recepcją Hermetica nie był jak dotąd, cytowany wyżej, fragment Jamblicha, od którego z pewnością zaczyna się stricte filozoficzne zainteresowanie hermetycznymi ideami. Jeśli więc zważymy na nieobecność De mysteriis w całym niemalże średniowieczu, zrozumiała się stanie swoistość postawy zajmowanej przez średniowiecze wobec Hermesa Trismegistosa. Aż do toledańskich kontaktów z Arabami, zachodnia Europa miała bowiem tylko fragmentaryczną wiedzę o hermetyzmie i ograniczała się ona, w gruncie rzeczy, jedynie do znajomości łacińskiego Asklepiusza oraz fragmentów przechowanych w pismach Ojców Kościoła ${ }^{29}$. Jednakże ani Asklepiusz, mimo jego wstrząsającej przepowiedni zniszczenia Egiptu, ani Divinae Institutiones pióra Laktancjusza nie dały wystarczających przesłanek do

26 Za koncepcją tą opowiada się np. G. Segal, op. cit., s. 11.

27 Iamblichus, De mysteriis, VIII, 4, transl. E. C. Clarke, J. M. Dillon, J. P. Hershbell, Society of Biblical Literature, Atlanta 2003, s. 315. O wpływie Jamblicha na recepcję tekstów hermetycznych w neoplatońsko-chrześcijańskiej tradycji por. również E. Des Places, Platonismo e tradizione cristiana, Celuc, Milano 1970, s. 193.

28 Por. C. S. Celenza, The revival of Platonic Philosophy, w: The Cambridge Companion to Renaissance Philosophy, ed. J. Hankins, Cambridge UP, New York 2007, s. 85. 29 Por. F. Ebeling, op. cit., s. 37; D. P. Walker, The Prisca Theologia in France, „Journal of the Warburg and Courtauld Institutes”, 1954, 17, s. 208. 
wyciaggnięcia wniosku o istnieniu jednolitej, pradawnej tradycji egipskiej $^{30}$. Stąd też obecność idei hermetycznych w średniowieczu pozbawiona była siły tej nadzwyczajnej auctoritas, jaką, wraz z przyswojeniem neoplatonizmu, otrzymała dopiero w renesansie. Dlatego, nawet jeśli rzeczywiście odnajdujemy przejawy zainteresowania postacią Hermesa Trismegistosa u takich średniowiecznych myślicieli, jak Teodoryk z Chartres, Albert Wielki czy Roger Bacon ${ }^{31}$, to i tak zainteresowanie to ma zupełnie inny charakter niż u myślicieli z końca XV w. Nawet Kuzańczyk, który niewątpliwie całą swoją filozofię opiera na hermetycznej koncepcji coincidentia oppositorum, wciąż — mimo znacznego obeznania z Asklepiuszem — nie wykazuje historycznej świadomości jej znaczenia ${ }^{32}$.

Istotne novum pojawia się dopiero po r. 1450, gdy przetłumaczony na nowo z greki tekst De mysteriis Jamblicha przywrócił hermetyzmowi właściwe miejsce. Pierwsze ślady recepcji traktatu odnajdujemy u wspomnianego wcześniej Ficina już około r. 1456. W swej szkolnej mowie, De laudibus philosophiae, powołując się, między innymi, na Jamblicha, wspomina on o wywodzącej się od Egipcjan i Arabów tradycji prisca theologia ${ }^{33}$. Dopiero dzięki tak rozumianej

30 Por. A XXIV-XXVI, s. 200-203. Wprawdzie Laktancjusz wspomina o „tradycji mędrców” przed pojawieniem się — wewnętrznie zróżnicowanej, bo pozbawionej znajomości prawdy - filozofii, lecz utożsamia ją z istnieniem siedmiu greckich mędrców (Lactantius, Divine Institutes, IV, I, 9, transl. A. Bowen, P. Garnsey, Liverpool UP, Liverpool 2003, s. 226) i gdy nawet zauważa, iż do kultury greckiej weszła pewna grupa wschodnich (Laktancjusz wymienia tutaj Egipcjan, Magów i Persów) idei, to jednak uwagę tę kończy zdziwieniem, dlaczego Grecy nie przejęli niczego od Żydów, chociaż oni, jako jedyni, znali w owym czasie prawdę (ibidem, IV, II, 4, s. 227).

31 Do średniowiecznych myślicieli, u których znajdują się odwołania do idei z Hermetica, należą m.in.: Teodoryk z Chartres, Alan z Lille, William z Auvergne, Robert Wielki, Albert Wielki, Mistrz Eckhart, Berthold z Moosburga, Thomas Bradwardine, Hugo od św. Wiktora, Bernard z Treviso. Por. N. Goodrick-Clarke, op. cit., s. 34; P. Arfé, The Annotations of Nicolaus Cusanus and Giovanni Andrea Busti on the "Asclepius”, „Journal of the Warburg and Courtauld Institutes”, 1999, 62, s. 35, przyp. 31 (obszerna bibliografia przedmiotu).

32 Posiadany przez Mikołaja z Kuzy manuskrypt zawierający tekst Asklepiusza ma sporo uwag poczynionych ręką Kuzańczyka. 144 odnoszą się do samego Asklepiusza. Nie dziwi więc, że wiele z głoszonych przez niego idei ma — jak wykazał P. Arfé (Id., op. cit., s. 29-31, 36-42) - hermetyczne korzenie.

33 Por. J. Hankins, Plato in the Italian Renaissance, Brill, Leiden 1994, s. 460-461. $\mathrm{Na}$ temat koncepcji prisca theologia u Ficina por. D. Nowakowski, Prisca theologia i jej znaczenie w metafizycznym systemie Marsilia Ficina, „Kronos” (w druku). 
historycznej tradycji, łączącej Hermesa Trismegistosa ze znacznie późniejszymi filozofami, mogło dokonać się w pełni świadome, filozoficzne, przyswojenie Hermetica, w przypadku Ficina związane z odnowieniem filozofii platońskiej ${ }^{34}$. Kiedy więc w 1460 r., na zlecenie Cosima de Medici, grecki manuskrypt Corpus Hermeticum został przywieziony z Macedonii przez „uczonego i prawego mnicha” ${ }^{35}$, Leonarda z Pistoi, Ficino doskonale zdawał już sobie sprawę z jego zawartości. Przełożone na łacinę (1463) i opatrzone zaczerpniętym z pierwszego traktatu tytułem Pimander dzieło poprzedził znaczącą przedmową, w której w sposób niedwuznaczny nawiązuje do Jamblichowego fragmentu:

Merkury napisał tę księgę po egipsku, a później, równie uzdolniony w języku greckim, tłumacząc ją, przekazał Grekom misteria Egipcjan („Aegyptiorum mysteria”). ${ }^{36}$

Przedmowa ta, powielona w licznych późniejszych wydaniach $P i-$ mandra, nie tylko rozpowszechniła przekonanie o egipskich korzeniach Hermetica, ale także dała uczoną podstawę dla uznania Hermesa Trismegistosa za pierwszego teologa w ogóle. Ficino podkreślał:

Był on pierwszym wśród filozofów, który zwrócił się od naturalnej filozofii i matematyki ku kontemplacji boskości. Był on pierwszym, który rozprawiał z najwyższą mądrością o majestacie Boga, porządku demonów i przemianach dusz. Tak więc, on pierwszy został nazwany założycielem teologii $[\ldots] .{ }^{37}$

34 Por. M. J. B. Allen, op. cit., s. 40; C. S. Celenza, Pythagoras in the Renaissance: The Case of Marsilio Ficino, „Renaissance Quarterly”, 1999, 52, s. 675. Na rolę Hermesa Trismegistosa jako protoplasty tradycji prisca theologia zwrócił Ficino uwagę już w roku 1457 w De divino furore, będącym komentarzem do Platońskiego Fajdrosa.

35 M. Ficino, Argumentum ad Pimandrum, s. 1837. Por. C. Salaman, Echoes of Egypt in Hermes and Ficino, w: Marsilio Ficino: His Theology, His Philosophy, His Legacy, ed. M. J. B. Allen, V. Rees, M. Davies, Brill, Leiden 2002, s. 115; W. Shumaker, op. cit., s. 201.

36 M. Ficino, Argumentum ad Pimandrum, s. 1837. Por. też B. P. Copenhaver, Iamblichus, Synesius and the Chaldean Oracle in Marsilio Ficino's „De vita libri tres”, w: Hermetic Magic or Neoplatonic Magic, Supplementum Festivum: Studies in Honor of Paul Oskar Kristeller, ed. J. Hankins, J. Monfasani, F. Purnell Jr, Medieval \& Renaissance Texts \& Studies, Binghamton — New York 1987, s. 448-452.

37 M. Ficino, Argumentum ad Pimandrum, s. 1836. 
Pierwsze wydanie Pimandra w 1471 r. pociągnęło za sobą powstanie innych, mniej lub bardziej wyraźnie odwołujących się do hermetycznej tradycji, pism, ale również — specyficzne pobudzenie popularnej wyobraźni. Za pierwszy jego przejaw uznać należy słynną marmurową posadzkę ułożoną w 1481 r. w sieneńskim Duomo. Przedstawia ona właśnie Hermesa Trismegistosa w otoczeniu słuchających go uczniów ${ }^{38}$. Drugim zaś było niezwykłe zjawienie się w Rzymie apokaliptycznego proroka Giovanniego Mercuria da Correggio i jego równie niezwykłego ucznia, Lodovica Lazzarelliego, od których zaczęliśmy naszą opowieść.

Lodovico Lazzarelli ${ }^{39}$ urodził się 4 lutego 1447 r. Gdy rozpoczął naukę u bliżej nieznanego Christoforo da Montone, dał się poznać jako niezwykle uzdolnione dziecko. Wkrótce też zaczął tworzyć różnego rodzaju poezje, systematycznie je gromadził i układał w niewielki zbiór. Szczytem jego młodzieńczych zdolności był, zaginiony obecnie, heroiczny poemat napisany z okazji bitwy pod San Flaviano (lipiec 1460). Lazzarelli wiódł życie typowego renesansowego humanisty, najmował się jako nauczyciel w co bogatszych arystokratycznych domach, pisał poematy (Carmen de apparatu Patavini hastiludii, 1468) i hymny, a nawet, w 1468 r., za mowę De laudibus poesis et de dignitate poetica, został uwieńczony przez samego cesarza, Fryderyka III, poetyckim laurem. Odtąd szczycił się, co podkreślał z dumą również jego brat Filippo w tytule swego Vita Ludovici Lazzarelli, chlubnym mianem Poeta Laureatus. Jednakże nawet tak dojrzałe literacko dzieło, jak pochodzące z lat 1468-1469 De gentilium deorum imaginibus, nie odwołuje się do hermetycznych idei, chociaż zawierało ono długi poemat o Merkurym. Utwór pokazuje świat pogańskich bogów całkowicie zgodny ze, znaną już z Boccaccia, grecką mitologią.

Zmianę przyniósł dopiero, tworzony na przestrzeni wielu lat, poemat Fasti Christianae religionis (1473-1480, ale poprawki jeszcze do 1495), w którym pojawiły się aż trzy, ujawniające znajomość Corpus Hermeticum, nawiązania do Hermesa Trismegistosa. Nie wiemy jednak, czy inspi-

38 Por. też B. Copenhaver, Hermes Theologus: The Sienese Mercury and Ficino's Hermetic Demons, w: Humanity and Divinity in Renaissance and Reformation, ed. J. W. O’Malley, T. M. Izbicki, G. Christianson, Brill, Leiden 1993, s. 149, 152 i n.

39 Dane biograficzne o Lazzarellim czerpię tutaj z trzech źródeł: F. Lazzarelli, Vita Lodovici Lazzarelli, w: Id., The Hermetic Writings..., s. 283-310; W. J. Hanegraaff, op. cit., s. 8-100; Dictionary of Gnosis and Western Esotericism, ed. W. J. Hanegraaff, A. Faivre, R. van den Broek, J.-P. Brach, Brill, Leiden 2006, s. 679-683. 
racją dla tych hermetycznych zainteresowań był kontakt, jaki w 1473 r. nawiązał Lazzarelli ze słynną Akademią Rzymską Pomponiusza Leta, czy też rzeczywiście - jak sam twierdził w nieco późniejszym Epistola Enoch - zainspirował go sam Giovanni Mercurio da Correggio. Tak czy inaczej, obrany około $1481 \mathrm{r}$. kierunek poszukiwań zaowocował noszącymi piętno hermetyzmu pracami, w tym: przedmowami do Pimandra, Asklepiusza, i tłumaczonymi przez Lazzarellego Definicjami dla Asklepiusza (po 1482), Opuscula de Bombyce (1486) i Epistola Enoch (1490). Za kulminację hermetycznych zainteresowań uznać należy, szczególnie nas tutaj interesujące, dzieło z lat 1492-1494 pt. Crater Hermetis. Wkrótce po jego napisaniu Lazzarelli nawiązał kontakt $\mathrm{z}$ alchemikiem Johannesem Rigaudem de Branchiis, pod wpływem którego zaczął interesować się alchemią. Pokłosiem nowych pasji był Tractatus de Alchimia (po 1495) gromadzący teksty pseudo-Lulliańskie. Pięć lat później (1500) Lazzarelli zmarł na zapalenie płuc w wieku pięćdziesięciu trzech lat.

Można zapytać tutaj, czy warto nieco zapomnianej postaci Lodovica Lazzarelliego poświęcać jeszcze, po z górą pięciuset latach, uwagę? Pytanie to jest o tyle istotne, że przez całą niemal drugą połowę XX w. Lazzarelli nie cieszył się zbytnim uznaniem badaczy i nawet tak ważna książka Frances Yates, Giordano Bruno and the Hermetic Tradition (1964), traktuje Lodovica jako myśliciela drugorzędnego, stojącego za Ficinem, Pico della Mirandola, Agrippą von Nettesheim i Giordano Bruno. Wbrew temu jednak należałoby skwapliwie potwierdzić znaczenie Lazzarelliego dla historii hermetyzmu. Przecież już nie tylko ideowa treść jego życiowego dzieła, Crater Hermetis, stanowiła wcielenie hermetyzmu w najczystszej postaci ${ }^{40}$, ale i on sam, co wcale nie było tak powszechne u myślicieli odwołujących się do Hermesa Trismegistosa, jednoznacznie identyfikował się z tą filozofią. „Hermetystą jesteś, jak się zdaje, o Lazzarelli” — zwraca się do niego jeden z bohaterów dialogu Crater Hermetis i chwilę później Lazzarelli rozwiewa wszelkie wątpliwości, mówiąc:

Jestem chrześcijaninem, [...] lecz nie wstydzę się być jednocześnie hermetystą. Jeśli będziesz badał jego [tj. Hermesa Trismegistosa] nauki, odkryjesz, że nie stoją one w sprzeczności z chrześcijaństwem. ${ }^{41}$

40 Por. W. J. Hanegraff, op. cit., s. 2, przyp. 1.

${ }_{41}$ „Hermeticus, ut videris, o Lazzarelle [...]. Christianus ego sum, [...] et hermeticum simul esse non pudet: si enim praecepta eius consideraveris, a Christiana confirmabis non abhorrere doctrina" (L. Lazzarelli, Crater Hermetis (właśc. Ludovici 
Dołączenie Crater Hermetis do ważnego wydania Corpus Hermeticum Jacquesa Lefevre'a d'Etaples (w 1505 r.) wpłynęło na zakorzenienie się w powszechnej świadomości związku Lazzarelliego z traktatami Hermetica. Sprawiło także, że jego utwór i on sam wpisali się na trwałe w dalsze dzieje już nie tylko hermetyzmu, lecz także hermetycyzmu i wszelkiej maści ezoteryzmów w ogóle. Tak więc, jeśli chcemy podjąć kwestię hermetycznej wizji zbawienia w renesansie, zmuszeni jesteśmy zająć się Crater Hermetis, poświęconemu „drodze wiodącej do życia”“2.

Crater Hermetis jest dialogiem wzorowanym na dialogach z Corpus Hermeticum. Biorą w nim udział trzy osoby: wprowadzający w hermetyczne nauki Lazzarelli, pobierający je król Ferdynand Aragoński oraz towarzyszący im humanista, Giovanni Pontano. Akcja rozgrywa się na przestrzeni kilku godzin. $\mathrm{Na}$ początku dowiadujemy się, że król będzie odpoczywał (LC 2. 1, s. 168), a zatem, najprawdopodobniej, rozmowa zaczyna się wczesnym wieczorem. Koniec dzieła zaś wieńczy wiadomość, że Lazzarelli, pożegnawszy swoich towarzyszy, odchodzi w ciemną już noc (LC 30. 6, s. 268). Te kilka godzin wystarczy jednak, by ujawnić „największy z wszystkich sekret”, a mianowicie: „czym jest ostateczny i doskonały owoc drzewa życia”, od którego „niczego bardziej nie może pragnąć człowiek na tym świecie" ${ }^{33}$. Tak wielka tajemnica wymaga, rzecz jasna, szczególnej ostrożności, dlatego też, gdy wszystko się już dokonało, Lazzarelli przestrzega, by jego rozmówcy ukryli w swej świadomości to, co „wyemanowało z czystego źródła prawdy” tak, aby „żadna niewierząca czy niedoświadczona, czy nieokrzesana [osoba] nie mogła tego usłyszeć” ${ }^{44}$.

Lazzarelli Septempedani Poetae Christiani ad divum Ferdinandum Ar. Siciliae Regem de summa hominis dignitate dialogus qui insscribitur Vita Christi et Crater Hermetis), 4. 1, w: Id., The Hermetic Writings..., s. 172 (cytowane dalej jako LC). Pogodzenie hermetyzmu z chrześcijaństwem było możliwe dzięki utożsamieniu postaci Chrystusa z Poimandresem: „[...] laudabo itaque Christum Iesum sub Pimandri nomine” (LC 30. 4, s. 262. Por. T. Churton, op. cit., s. 55; W. J. Hanegraaff, op. cit., s. 20, 61).

42 "Cum mecum ipse diu haesitarem, inter tot et veterum et recentium diversas dissonasque opiniones, quae ad vitam duceret via [...]” (LC 1. 1, s. 166).

43 Por. „Ardeo enim, optime Rex, tibi in nostri fine sermonis secretorum maximum revelare quod ligni vitae fructus ultimus est et perfectus adeo, quia in hac vita nihil est quod ulterius homo desiderate possit” (LC 11. 5, s. 198).

44 "Quod et vos, si non desistitis, aperte cognoscientias clausum retinete, ne quis incredulus, imperitus ac rudis id audiat" (LC 28. 1, s. 254). 
Mamy więc do czynienia $\mathrm{z}$ pismem w najwyższym stopniu ezoterycznym, którego autor, jak sam zresztą napomyka ${ }^{45}$, boryka się z wyraźnymi trudnościami przy próbie przekazania treści swych nauk. $\mathrm{I}, \mathrm{w}$ istocie, nie powinna nas ta nieporadność dziwić, skoro ową treść podpowiadają mu nie tylko księgi czy rozum, ale i samo jednostkowe i niewyrażalne przeżycie (LC 19. 2, s. 224). Jeśli więc tyko zechcemy uznać to hermetyczne doświadczenie za jedną z odmian doświadczenia mistycznego - ku czemu zresztą sam się tutaj skłaniam - to i Lazzarelliego powinniśmy uważać za czystej krwi mistyka hermetyczno-chrześcijańskiego ${ }^{46}$. Badając zatem jego wskazówki dla poszukujących drogi życia, nie możemy nigdy tracić z oczu podstawowych wyznaczników określających tę jego orientację. Mógłbym wprawdzie przedstawić tutaj samą zbawczą praktykę w oderwaniu od metafizyczno-eschatologicznego tła, lecz — uczciwie przyznaję - byłoby to działanie kuriozalne.

Warunkiem sine qua non wszelkich duchowych poszukiwań jest, podkreśla Lazzarelli, oderwanie od natłoku codziennych zajęć, wolny czas $^{47}$. Negotium, wydobywając nasze jestestwo z powszechnego dziania się świata, stawia nas wobec nieodpartego pytania o rzeczy pierwsze i ostatnie, o śmierć, życie i szczęście (por. LC 1. 1, s. 166; 2. 2, s. 170). Znalezienie odpowiedzi nie jest łatwe, jak głosi cytowany przez Lazzarelliego Porfiriusz: „[...] bardzo twarda jest owa droga i zamknięta brązowymi wrotami, która prowadzi nas do życia i obdarza szczęściem" ${ }^{48}$. Poszukiwania we właściwy sposób zainicjować może tylko poznanie samego siebie.

$\Gamma v \tilde{\omega} \theta l \sigma \varepsilon \alpha v \tau o ́ v$ - tak brzmiała odpowiedź na pytanie zadane delfickiemu Apollinowi o drogę do szczęścia i taki też widniał napis nad wejściem do jego świątyni (LC 2. 3, s. 170), przypomina autor Crater

45 Por. LC 7. 3, s. 186.

46 Por. J. Miernowski, Bóg-Nicość. Teologie negatywne u progu czasów nowożytnych, przeł. M. Abramowicz, IFiS PAN, Warszawa 2002, s. 97. Sam Lazzarelli, jak wyznaje (LC 7. 3, s. 186), pragnął pozostać w granicach katolickiej ortodoksji (por. F. Lazzarelli, Vita..., s. 300).

47 Por. „Otiosus enim videris et huic de qua nunc tecum acturus sum perscrutationi idoneus [...]" (LC 2. 1, s. 168).

48 „Dura via illa nimis aetatis clausaque portis, quae vitam nobis aperit donatque beatam [...]" (LC 3. 1, s. 170). 
Hermetis. Dalej podkreśla, że postulat samopoznania pojawia się też w dawniejszych naukach Hermesa:

Hermes mówi, że Bóg, stworzywszy na począ̧tku wszystkie rzeczy, zawołał: „Pnijcie się, wzrastajcie i rozsiewajcie wszelkie kiełki i moje dzieła. Wy nadto, którym udzielono udziału w umyśle, rozpoznajcie swój rodzaj i rozważcie swoją nieśmiertelną naturę, i poznajcie, że przyczyną śmierci jest cielesna miłość”. ${ }^{49}$

Następnie Lazzarelli wyjaśnia królowi Ferdynandowi, w jaki sposób najdoskonalej poznać samego siebie:

Proszę, teraz uważajcie. Tak jak nie możemy rozpoznać obrazu w lustrze czy na monecie, jeśli wcześniej nie poznamy, tego, z czego on pochodzi lub co przedstawia, tak też póki nie poznamy Boga, nie możemy w żaden sposób poznać nas samych: rzeczy te są bowiem nawzajem powiązane tak, że nie znając jednego, nie znamy drugiego. ${ }^{50}$

Tym samym, gdy u Kartezjusza poznanie Boga stało między poznaniem siebie a poznaniem świata, tak tutaj poznanie Boga jest warunkiem nawet samego rozpoznania swojej tożsamości. I podobnie, jak u Kartezjusza, położenie nacisku na wiedzę o Bogu przywołuje od razu kwestię możliwości rozumowego poznania Boga. Czyż nie mówi Pismo, że Bóg nie może być poznany? Czyż nie napisano, że „Nikt nie zna Syna, tylko Ojciec i nikt nie zna Ojca, tylko Syn i ten, którego Syn wybrał, by mu to objawić”? (LC 19. 1, s. 224).

Słuszne są, przyznaje Lazzarelli, te zarzuty, lecz stosują się tylko do poznania Boga w jego najgłębszej istocie. Prawdą jest bowiem, że nie możemy poznać „Boga w sobie, jako oddzielonego od rzeczy, jako we wszelki sposób siebie w sobie zamykającego lub jako samotnie i naj-

49 „Creatis initio omnibus, sic Deum Hermes asserit exclamasse: «Pullulate, adolescitel, propagate universa germina ac opera mea. Vos insuper, quibus mentis portio concessa est, genus recogniscite vestrum vestramque naturam immortalem considerate, amorem corporis mortis causam esse scite»" (LC 6. 2, s. 182; CH I, 18).

50 „Ergo attende. Sicut enim quae videtur in speculo aut in numismate imaginem neqimus agnoscere ni a quo resultet sive quem refeat prius dignoscamus, it nisi Deum noverimus nos ipsos cognoscere ullo pacto non possumus: connexa enim ad invicem haec sunt, ut ignorato uno ignoretur et alterum" (LC 18. 2, s. 220). 
skrajniej wycofanego w najgłębsze głębie swojej boskości i trwającego w ciemni”. Zaiste, ludzki intelekt nie zdoła wspiąć się na takie szczyty ${ }^{51}$.

Gdy jednak skierujemy swoją uwagę na Boga Stwórcę, który zechciał się człowiekowi objawić i ukazać poprzez uczestniczące w Nim stworzone rzeczy (por. LC 19. 5, s. 226), jednak w jakiś sposób poznajemy go. Dwa są zatem, według autora Crater..., źródła rozumowej wiedzy o Bogu: stworzony świat i objawienia świętych Ojców. Pierwsze z nich — jak mówi Platon w Alkibiadesie — jest „pełnym zagadek poematem" (LC 13. 4, s. 206) danym nam jako środek wiodący nasz umysł do poznania Boga (LC 9. 3, s. 190). Drugie - to zawarta w pismach wiedza o niedostępnych naturalnemu poznaniu rzeczach: o stworzeniu świata i człowieka oraz o świętej Trójcy (LC 20. 1-20. 4, s. 226-228) ${ }^{52}$. Aktem umysłu, pozytywnie ustosunkowującego się wobec tych prawd, jest wiara.

Poznanie Boga jako Stwórcy ujawnia nam od razu prawdę o godności ludzkiego pochodzenia. Poznanie Boga jako Zbawcy potwierdza wielkość człowieka nawet po jego upadku, tak bardzo Bóg bowiem wywyższył człowieka, że, zstąpiwszy do niego z wieczności, przywdział ciało i sam stał się człowiekiem ${ }^{53}$. W taki oto sposób od poznania Boga dochodzimy do poznania samych siebie, od poznania Stwórcy — do stworzonego człowieka.

Duma płynąca z tego poznania jest tak wielka, że słysząc słowa średniowiecznego hymnu Dies irae, hermetysta nie czuje dłużej potrzeby lękliwego korzenia się przed obcym Bogiem, lecz z nadzieją spogląda w górę na prawdziwego Ojca. Rozpoznaje on, w swym wnętrzu, umysł i słowo, prawdziwy obraz Boga, a jego dusza, będąca — jak głoszą kabalistyczne nauki - Bożą światłością, jaśnieje prawdziwym światłem Bo-

51 „Non igitur hic moneo nos Deum nosse oportere ut qualis is sit in sui a rebus separatione, qualis in omnimoda sui in se ipso clausione, qualisve in extrema ac solitaria in profundissimum suae divinitatis recessum ac calignem retractatione, quaeve eius sit substantia dignoscamus: hoc enim difficile nimis, immo impossibile, nam humanus tantum nequit ascendere intellectus” (LC, 19.3, s. 224).

52 Por. „Et ea omnia de divinitate nos credere oportet, quae a sanctis patribus per canonum instituta definita sunt [...] Sed quod nos idoneos mysterio quod revelaturus sum optimeque dispositos faciet, id erit ut meditemur quia Deus est omnium causa omniumque creator omniaque propter divinum praecipuumque animal, ipsum videlicet hominem, creavit" (LC 20. 4, s. 228).

53 Por. „Adeo Deus hominem magnifecit ut ab aeternitate in tempus descenderet amictumque carnis accipiens Deus homo factus est" (LC 20. 5, s. 228). 
żym ${ }^{54}$. Odrzuca więc Lazzarelli nauki księży, którzy zrównują człowieka ze zwykłym prochem. Mówiąc: „Pamiętaj człowiecze, że prochem jesteś i w proch się obrócisz", zmuszają oni człowieka do dobrych uczynków, jak gdyby był niewolnikiem. Zamiast tego autor Crater Hermetis proponuje istocie ludzkiej drogę godną Syna Bożego i przywołuje słowa Hermesa:

Pamiętaj człowiecze, pamiętaj, że światło i życie są Bogiem i Ojcem, z którego człowiek jest zrodzony. Przeto, jeśli widzisz siebie jako utworzonego ze światła i życia, do światła i życia wstąpisz ponownie. ${ }^{55}$

Poznaniem prawdziwej, boskiej, istoty kończy się dla człowieka pierwszy akt hermetycznej drogi zbawienia przygotowujący do dalszych, bardziej jeszcze wzniosłych etapów wędrówki:

Tak bowiem poznawszy wspaniałość swojej substancji, w żaden sposób siebie nie zlekceważysz ani siebie nie odrzucisz, ani w błoto nie powalisz, lecz wyszedłszy z ciała i uwolniony od siebie samego oraz od wszelkich rzeczy zmysłów, wzlecisz absolutnym i czystym opuszczeniem ku nadsubstancjalnej i najświatlejszej ciemności, gdzie zamieszkuje Bóg i zajmiesz miejsce wśród licznych Mocy i — będąc przyjętym w ich obręb — będziesz radował się Bogiem i zradzając $\mathrm{z}$ tego boskie potomstwo, będziesz wydawał je dla Boga, nie dla siebie. Bowiem podobne zawsze jest wydawane z sobie podobnego. ${ }^{56}$

54 Por. LC 23. 2, s. 238; LC 23. 2, s. 236.

55 „Ego vero, o pie Rex, ut firmius huic sacro insistes operi te sedulo admonebo, non quem ad modum imposito cinere populum sacerdotes monent: «memento homo quia cinis es et in cinerem reverteris» (hi enim exteriorem et mundanum monent hominem, et ceu servum ad bona officia timore compellunt); sed te tamquam interiorem et substantialem hominem et tamquam Dei filium amore quodam ingenti, his Hermetis verbis alliciam: «reminiscere, homo, reminiscere quia lux et vita Deus est et pater, ex quo natus est homo. Si igitur te ipsum comprehenderis ex luce ac vita compositum, ad lucem rursus vitamque transcendes»" (LC 21. 5, s. 230-232). Por. też CH I, 21.

56 „Sic enim excellentiam substantiae tuae comperiens, non te utique negliges, non abicies, non in coenum prosternes, sed emergens e corpore, a te ipso et ab omnibus sensibilibus libere, absolute et pure excedendo, ad supersubstantialem lucidissimiamque caliginem, ubi Deus inhabitat, evolabis, teque in potestatum numerum conferes, receptusque inter potestates Deo frueris, divinamque deinceps sobolem procreando, Deo, non tibi, propagabis. Nam semper simile a suo simili procreatur" (LC 21. 4, s. 230). 
Król Ferdynand (reprezentujący każdego oświecanego nowicjusza) wpada pod koniec nauk o swej prawdziwej naturze w ekstazę i doświadcza ontycznej przemiany. Lazzarelli objaśnia, że stopniowo, dzięki tego rodzaju kontemplacji, będzie odnawiany przez boskie światło i przekształcany w prawdziwego człowieka.

Nim jednak przejdziemy do drugiego aktu opisywanej tutaj hermetycznej inicjacji, podsumujmy krótko rezultaty osiągnięte w pierwszej części. Rozpoznanie swojej prawdziwej istoty i doznane tym samym oświecenia równoznaczne jest $\mathrm{z}$ uczestniczeniem człowieka $\mathrm{w}$ najwyższej mądrości (por. LC 14. 2, s. 208), dzięki temu zaś uczestnictwu człowiek spontanicznie wpisuje się w boski porządek, osiągając we własnym działaniu cel stworzenia (LC 22. 2, s. 232). Innymi słowy, ponawiany wielokrotnie akt kontemplacji pełni funkcję oczyszczająca, wydobywa wewnętrzne i substancjalne człowieczeństwo, „prawdziwego człowieka” (,verus homo").

Dalej, odpowiadając na królewskie pytanie o korzyści z kontemplacji, Lazzarelli dowodzi, że człowiek oddający się studiowaniu swym umysłem boskich tajemnic osiąga szczęście i „buduje [...] w sobie czystą i godną świątynię, w której będzie mógł zamieszkać Bóg”57.

Lazzarelli nawiązuje w ten sposób nie tylko do 1 Listu do Koryntian $(3,16)$, ale także do hermetycznego wątku „krateru” lub też „czary mądrości Nous”. Kiedy jednak w Corpus Hermeticum owa „wielka czara” spełnia jedynie funkcję źródła mądrości, u Lazzarelliego świętym naczyniem wydaje się zarówno źródło mądrości, jak i człowiek, na którego ta mądrość jest przelewana ${ }^{58}$. Jak możemy się już domyślać, w drugim akcie będzie miało miejsce wypełnianie owego naczynia, rodzenie się „owocu życia”, a nawet — jak podkreśla autor Crater Hermetis — „stwarzanie Boga”.

Analizując drugi akt inicjacji, dotykamy najbardziej newralgicznego i najbardziej oryginalnego punktu doktryny Lazzarelliego, jego „najnowszej nowości z nowości i cudu daleko większego, niż wszystkie inne, [mianowicie] że człowiek odkrył naturę Boga i wie, jak go

57 „Nam praeter animi felicitatem, quae per sapientiam evenit, se purum dignumque templum statuebat in quo Dei spiritus inhabitaret [...]" (LC 8. 2, s. 188). Por. LC 15. 2, s. 212; 23. 2, s. 238; Epistola Enoch 6. 4. 2, s. 122; A XI, s. 184-186.

58 Por. CH IV, 3-4. Warto podkreślić, że Lazzarelli, prócz hermetycznego terminu crater Hermetis, używa jeszcze zamiennie chrześcijańskiego terminu calix Christi. Motyw kielicha Chrystusa pojawia się również w Epistola Enoch (4. 5, s. 114). 
stworzyć" 59 . To szokujące dla nas wyznanie ma swe źródło w jednym $\mathrm{z}$ najtrudniejszych do interpretacji miejsc w całych Hermetica: fragmentu Asklepiusza, poświęconego egipskim obrzędom tworzenia idoli (A XXIII-XXIV). Passus ten był przez chrześcijańskich myślicieli albo potępiany jako przejaw demonicznej magii, albo też traktowany jako dodatek Apulejusza z Madaury ${ }^{60}$. Lazzarelli zaś, przeciwnie, przekonany o prawdziwości całej nauki Hermesa Trismegistosa, uczynił z tego trudnego fragmentu jądro swej doktryny i w najciemniejszym miejscu hermetyzmu dostrzegł najjaśniejsze światło.

Skłonny jestem uważać, że cezurę rozdzielającą dwa tak często wspominane przeze mnie akty hermetycznego dramatu stanowi pojawiający się mniej więcej w dwóch trzecich dialogu „hymn kontemplacji” (LC 23. 2, s. 233-240). Wyrażona w nim pochwała zarówno umysłu, jak i Boga Ojca, a nawet Zbawiciela, wyzwala w słuchającym go królu Ferdynandzie „ogromną miłość do Boga” (LC 24. 1, s. 242). Miłość ta — jak chwilę później dodaje Lazzarelli — odgrywa bardzo ważną rolę w hermetycznym zbawieniu:

Przeto musimy dbać, by miłość ta trwała i wzrastała każdego dnia. Bowiem sama miłość przemienia niższe rzeczy w wyższe i jednoczy je ze sobą. Zaprawdę, kontemplacja wpierw wyzwala miłość, następnie miłość umysł ludzki kieruje ku Bogu. ${ }^{61}$

59 „Haec certe novitatum novitas nova, / et mirabilibus maius id omnibus, / naturam quia homo iam reperit Dei / atque ipsam sapiens facit” (LC 27. 1, s. 252).

60 Marsilio Ficino (w De vita) uważał (za Tomaszem z Akwinu), że opisywana tu procedura nie jest stwarzaniem Boga, lecz jedynie potępienia godną magią demoniczną. D. P. Walker w Spiritual and Demonic Magic (s. 42) uważa, iż Ficino godzi się na używanie demonów jako środka wiodącego do Boga, ale cytowany przez niego fragment łaciński informuje o tym, że podobną opinię wyrażał Jamblich. Por. M. Ficino, Three Books on Life. A Critical Edition and Translation with Introduction and Notes by C. V. Kaske, J. R. Clark, Medieval \& Renaissance Texts \& Studies, Binghamton New York 1989, s. 238. Wbrew temu, co wykazał Walker, z Ficinowego twierdzenia o pogańskiej idolatrii i demonach można wyprowadzić wniosek o możliwości używania demonów jako środka w poszukiwaniu najwyższego Boga. O problemie związanym z interpretacją omawianego fragmentu Asklepiusza por. F. Yates, op. cit., s. 6-12. 61 „Danda est in posterum opera ut talis perseveret amor et crescat in dies. Inferiora enim ipse amor ad superiora convertens, illa ad invicem unit pariter et connectit. Verum contemplatio amorem prius excitat, amor deinceps humanam mentem ad Deum convertit [...]” (LC 24. 2, s. 242). Znaczenie tej miłości u Lazzarelliego podkreśla również W. J. Hanegraaff, op. cit., s. 70. 
Dzięki tej miłości zostajemy doprowadzeni pod sam próg boskiej siedziby, w sam „przedsionek tej ciemności, w której zamieszkuje Bóg”" Rozpaleni Boską miłością dowiadujemy się wreszcie, że Bóg nie tylko kiedyś, raz jeden, stworzył świat, ale że i teraz jest „płodny bardziej od wszystkiego innego”. To właśnie dlatego nauki hermetyczne i orfickie hymny tak silnie podkreślały — mówi Lodovico — hermafrodytyczną naturę Boga (LC 24. 4, s. 242). Jego płodność, która nie jest płodnością ciała, lecz płodnością umysłu, udzielona została również człowiekowi tak, że i jego umysł może przynosić Boskie potomstwo:

Ponieważ ludzki umysł jest obrazem pierwszego umysłu, otrzymał on od niego nie tylko płodność, ale również nieśmiertelność: dwa te najważniejsze dary zostały dane przez sam umysł swemu obrazowi, to jest słowu. To właśnie dlatego Hermes mówi, że umysł i słowo są równie cenne co nieśmiertelność, i dlatego też upomina nas, by używać tych darów nie w inny sposób, niż czynią to nieśmiertelni [...]. Te dwa zaś połączone nawzajem [...] przynoszą boskie potomstwo. ${ }^{63}$

Lazzarelli dochodzi tutaj do najważniejszego punktu swojej nauki. Dzięki wyrafinowanej hermeneutyce udaje się mu pojednać dwie, wydawałoby się, sprzeczne tradycje: idolatryczną tradycję hermetyczną z soteriologiczną tradycją ewangelii. Punktem tym jest arcanum arcanorum, tajemnica odkrywana jedynie dzięki boskiemu objawieniu, mianowicie opis „tworzenia Boga” (LC 18. 1, s. 254). Odczytując kontrowersyjny fragment Asklepiu$s z a$, Lazzarelli, inaczej niż jego poprzednicy i następcy, identyfikuje magiczny wątek ożywiania posągów z ewangeliczną konwersją nowonarodzenia i w hymnie boskiego płodzenia wyjawia tę tajemnicę tajemnic:

To, co było ukryte przed starożytnymi / i z trudem mogło być powiedziane w parabolach, / chcecie bym wyraził wam w nagich wersach, / by ludzie mogli być łatwo pouczeni. [...] Słuchajcie, gdyż zaczynam: bądźcie cicho, / by wszyscy mogli słuchać chętnym uchem / moich słów, zapłodnieni Boską mową. I

62 „Nunc in vestibulo caliginis sumus, in qua Deis inhabitat” (LC 24. 3, s. 242). 63 „Mens humana, cum primae mentis sit imago, ab illa non solum fecunditate, verum etiam immortalitate donata est: quae quidem duo praecipusa munera suae imagini, videlicet sermoni, mens ipsa communicat. Propterea Hermes asseruit mentem et sermonem eiusdem cum immortalitate pretii esse, et quicumque his in eo quod congruit uteretur, nequaquam ab immortalibus monuit discrepare [...]. Haec enim duo [...] ad invicem coniugata divinam sobolem pariunt" (LC 25. 3, s. 244-246). 
Słuchaj, kładę me palce na lirze. To jest z pewnością najnowsza nowość z nowości / i cud daleko większy, niż wszystkie inne, / że człowiek poznał naturę Boga / i wie, jak go stworzyć. Bowiem tak jak Pan czy też Bóg stwórca / tworzy niebiosa i wydaje na świat anioły, / które są gatunkami rzeczy, głową wszystkiego / i pierwszymi wzorcami, / tak też prawdziwy człowiek tworzy Boskie dusze, / które starożytny tłum nazywał ziemskimi bogami, / co radują się życiem bliskim z ludźmi / i weselą ich dobrem. [...] Po to dał Stwórca człowiekowi / umysł podobny swojemu i mowę, / by, niczym bogowie, mógł on wydać bogów, / wypełniając przykazania Ojca. / Ten, co zna dary przeznaczenia, jest najszczęśliwszy; / chętnie je wypełni, / bowiem będzie wliczony między bogi / i od bogów wysokich niższy nie jest. ${ }^{64}$

Choć, co prawda, jak przypomina Lodovico, kwestie te poruszano już w Corpus Hermeticum, a w Asklepiuszu poświęcono im więcej miejsca (LC 29. 1, s. 256) ${ }^{65}$, to jednak dopiero Jezus Chrystus objawił ten sekret, potwierdzając go nie tylko słowami, ale i życiem (LC 29. 7, s. 260). Skoro, jak podaje Nowy Testament, istnieją dwa rodzaje narodzin, to muszą istnieć też dwa rodzaje płodzenia. I skoro ciało ma moc wytwarzania podobnego do siebie ciała, to jasne jest, że tego rodzaju zdolność rodzenia będzie miał i umysł (por. LC 26. 1, s. 246). Asklepiusz traktujący o „stwarzaniu Boga” nie stoi zatem w sprzeczności $\mathrm{z}$ ewangelią mówiącą o nowonarodzeniu.

Lazzarelli, zestawiając te tradycje, dostrzegł ideowe podobieństwo pomiędzy nimi i uznał, że przez to stanowią one jedność. Uzyskany w ten sposób amalgamat hermetyzmu z chrześcijaństwem, głoszący po-

64 „Quod priscis vetitum est, quodque parabolis / vix olim licuit dicere, nunc mihi / nudis das veniam promere versibus, / ut fiant dociles viri. / [...] En nunc incipio: muta silentiis, / pronis cuncta meos auribus audiant / divino gravidos eloquio sonos; / en tango digitais lyram. / Haec certe novitatum novitas nova, / et mirabilibus maius id omnibus, / naturam quia homo iam reperit Dei / atque ipsam sapiens facit. / Nam sicut Dominus vel genitor Deus caelestes generans procreat angelos, qui rerum species, qui capita omnium exemplaria primaque: / divas sic animas verus homo facit, / quod terrae vocitat turba vetus deos, qui gaudent homini vivere proximos, / laetanturque hominis bono. / [...] Mentem propterea persimilem sibi / sermonemque homini iam genitor dedit / ut diis consimilis parturiat deos, / Patris fataque compleat. / Felix ille satis qui sua noverit sortis munera, perfecerit et libens. / Inter namque deos connumerandus est, nec est diis superis minor" (LC 27. 1, s. 252-254).

65 Por. CH XIII. Niemal cały traktat poświęcony jest zagadnieniu nowonarodzenia. Dzieło kończy hymn na cześć nowonarodzenia (por. CH XIII, XVII i n.). 
wszechność i ponadczasowość tradycji prisca theologia, nie wszystkich satysfakcjonował. Niecałą dekadę później francuski wydawca Crater Hermetis, Jacques Lefevre d'Etaples, będzie powątpiewał w spójność rozwiązania Lazzarelliego:

Lazzarelli zrozumiał ten fragment poprzez analogie, jak gdyby idole były apostołami, a czyniący je człowiek - Chrystusem; cnotą zaś wlewaną w nich z góry — Duch Święty [...]. [I rzeczywiście] rzeczy te pobożnie były zamyślone, lecz prawdopodobnie zbyt mocno przekręcają ten tekst. Wraz z Augustynem przeczuwam, że tutaj, jak i w trzynastym traktacie Corpus Hermeticum, znajduje się jedna z Hermesowych pomyłek. ${ }^{66}$

Tak czy inaczej, inicjacja hermetyczna z Crater Hermetis doprowadza w końcu jej uczestników do przebóstwienia, tak silnie łączącego człowieka z Bogiem, że rzeczywiście stają się oni z nim jednością (por. LC 5. 3, s. 178). Całość wieńczy jeszcze niebiańska wizja powrotu do stanu rajskiej szczęśliwości sprzed popełnienia grzechu:

Spójrzcie, teraz jawią się wam rozkosze raju, ukazuje się niebiańskie miasto, otworem stoi wejście na górę do namiotu i do Bożego pałacu. Oto przedłożone jest przed wasze oczy królestwo Izraela, które poeci nazywali złotym wiekiem i o które modlić się uczył swoich uczniów Chrystus Jezus. Minęło sześć dni pracy i znoju, zajaśniał dzień Szabatu i odpoczynku, a prawda i mądrość wyszły naprzeciw. Oto z wnętrza mądrości wydobyto dla was skarb nieśmiertelności. Oto nektar, oto ambrozja, oto manna, oto ofiara i święto baranka, na które ptaki niebieskie zdążają, nakarmią was jako gości i zaproszonych przyjaciół. Drzewo życia później dostarczy wam aromatycznego balsamu. Duch wasz nie będzie [już] dłużej zatroskany i zmęczony. ${ }^{67}$

66 „Lazarelus hunc locum ad Analogiam trahit quasi idola apostoli sint; fictor homo, Christus; virtus desuper indita, spiritus sanctus [...]. Hec excogitata pie, sed ad litteram forte violenta. Lapsum Hermetis cum Augustino, $\&$ in hoc $\&$ in tertiodecimo capite, sentio" (cyt. za: D. P. Walker, Spiritual and Demonic Magic, s. 241-242).

67 „Ecce nunc vobis paradisi aperiuntur deliciae, caelestis revelatur civitas, ad montem, ad tabernaculum, ad aulam Dei patet accessus. En Israel regnum, quod poetae auream vocant aetatem, pro quo Christus Iesus docuit orare discipulos suos, vobis ante oculos proponitur. Sex operum laborumque dies transierunt, Sabati illuxit requies veritasque et sapientia obviam properant. En ex sapientiae adytis immortalitatis thesaurus vobis effoditur. En nectar, en ambrosia, en manna, en victima, en caena agni, ad quam volucres caeli properant, vos convivas pascet et hospites. Lignum vitae 
Historia dalszych dziejów traktatu Crater Hermetis jest raczej krótka. Po trwającym kilkanaście lat okresie fascynacji, jaką cieszył się on tuż po pierwszym wydaniu (zwłaszcza we Francji), jego popularność wyraźnie zmalała, przyćmiona bardziej znaczącymi — już chociażby objętościowo — dziełami Marsilia Ficina, Agrippy von Nettesheim czy Paracelsusa. Głoszone przez Lazzarelliego nauki nie tylko nie doprowadziły do spełnienia głoszonej przez niego millenarystycznej wizji ${ }^{68}$, ale także nie odbiły się szerszym echem w nauce i wierzeniach popularnych. Omawiany traktat do dzisiaj zajmuje w historii idei pozycję marginalną, a głoszone przez jego autora poglądy traktuje się częściej jako aberrację, niż jako rzeczywisty przedmiot namysłu. W swoim krótkim studium starałem się jednak ukazać, że mimo oczekiwanej przez nas naiwności (w pejoratywnym znaczeniu) doktryny Lazzarelliego (zwłaszcza w perspektywie jego spotkania z Mercuriem da Correggio), zachowuje ona logiczną spójność i mistyczną głębię.

\section{The Hermetic View of Salvation. Lodovico Lazzarelli (1447-1500) on the Background of the Culture of the Italian Renaissance}

The paper presents the doctrine and the views of the great Renaissance hermeticist, Lodovico Lazzarelli. Initially discussed is the relationship which bound him to his teacher and guide, Mercurio da Correggio, as described by Lazzarelli in his Epistola Enoch. Next, the paper looks at the nature and origins of hermetism, the definition of the term "hermetic" and the ongoing discussion around it. The history of the reception of Hermetica in the Renaissance and the place of Lodovico Lazzarelli within it are reconstructed in the latter half of the first part of the paper. The second part of the paper is devoted to the analysis of the main work of Lazzarelli, Crater Hermetis. The main theme of the treatise is the hermetic way of salvation. This way consists of the following stages: the knowledge of God, the knowledge of self and its own divine nature, purifying contemplation, the transforming love of God, and finally, the creation of God (the famous theme from Asclepius). The article ends with a discussion of Lazzarelli's attempts to reconcile his doctrine with Christian orthodoxy.

posthac erit vobis in odore unguenti. Non vester ultra laborabit, nec fatigabitur animus" (LC 26. 3, s. 248).

68 Por. LC 30. 5, s. 266. 